\title{
Heavy Metal Contamination Assessment of Groundwater Resources in Behbahan Plain Southwest Zagros
}

\author{
Zohreh Marbooti, Rezvan Khavari*, Farhad Ehya \\ Department of Geology, Behbahan Branch, Islamic Azad University, Behbahan, Iran \\ Email: ${ }^{*}$ Re khavari@yahoo.com
}

Received 12 April 2015; accepted 15 May 2015; published 18 May 2015

Copyright (C) 2015 by authors and Scientific Research Publishing Inc.

This work is licensed under the Creative Commons Attribution International License (CC BY). http://creativecommons.org/licenses/by/4.0/

(c) (i) Open Access

\section{Abstract}

Ground water is an important issue in environmental engineering and water supply systems, so preservation and purification of ground water have a critical role in any community. This paper investigates the concentration of several elements such as $\mathrm{Pb}, \mathrm{Cd}, \mathrm{As}$, Se, Co and $\mathrm{Zn}$ for ground water in Behbahan (a city in southwest of Iran), to this purpose a group of $\mathbf{3 0}$ wells were studied to determine the heavy metal concentration, physical parameters (PH, EC, TDS, Temperature) in situ. The major ions' values of $\mathrm{HCO}_{3}^{2-}, \mathrm{SO}_{4}^{2-}, \mathrm{Cl}^{-}, \mathrm{Na}^{+}, \mathrm{Mg}^{2+}, \mathrm{Ca}^{2+}, \mathrm{K}^{+}$were measured for the wells based on the titrimetrical and flame photometry and optical emission spectrophotometer. Results of the analyses indicated the concentration of $\mathrm{Pb}, \mathrm{As}$, $\mathrm{Cd}$ and $\mathrm{Se}$ in 33,13, 56, 100 percent greater than normal range of WHO standard respectively. No pollution of Co and Zn was seen in any specimen. There is a low correlation between $\mathrm{Pb}$ and major ions value, so it can be concluded that $\mathrm{Pb}$ overconcentration is caused by human contamination. The high correlation between Se, As and major cations and anions, implies that they can originate from dissolution and liquidation of mineral evaporation in the zone. The high rate of Cd concentration in urban sewage water is due to the small industries, workshops and mills wastewater.

\section{Keywords}

Heavy Elements, Ground Water, Pollution, Waste Water

\section{Introduction}

Over the last few decades, competition for economic development, associated with rapid growth in population

*Corresponding author.

How to cite this paper: Marbooti, Z., Khavari, R. and Ehya, F. (2015) Heavy Metal Contamination Assessment of Groundwater Resources in Behbahan Plain Southwest Zagros. Open Journal of Geology, 5, 325-330.

http://dx.doi.org/10.4236/ojg.2015.55029 
and urbanization, has further affected the groundwater quality due to over exploitation and increasing demand for agriculture, domestic and industrial water supply, as well as improper sewage flow and solid waste disposal [1] [2]. The effluents discharged from industries and urban sewage find their way into surface water bodies. These water bodies in turn act as recharge source for groundwater, thus making it vulnerable. Few of the heavy metals considered as micronutrients become detrimental to human health when their concentrations exceed the permissible limits [3]. The present study tries to quantify the heavy metal pollution, in Behbahan plain of ground water along with its suitability for drinking purposes. The importance of this subject is highlighted if we know that some part of drinking water of the urban and rural residential areas is provided from the ground water in the study area.

\section{Geological Setting}

Study area is Behbahan Plain with an area of about $1320 \mathrm{~km}^{2}$ and is located between $30^{\circ} 30^{\prime}$ and $31^{\circ} 00^{\prime}$ northern and $50^{\circ} 00^{\prime}$ and $50^{\circ} 30^{\prime}$ eastern, southeastern part of Khuzestan province and southwest of Iran (Figure 1). This area is a part of Jarrahi river catchment area that located in the south and southwest of middle Zagros domain. Climate of the study area is semiarid, the annual average precipitation being approximately $336 \mathrm{~mm}$. The annual potential evaporation exceeds the annual rainfall with amount of approximately $3401 \mathrm{~mm}$. In this area generally, slope decreases from north to southeast and southwest.

Geologically, the study area lies in the Zagros folded belt (stocklin, 1968). Outcrop of the Formations in the study area is related to Upcrertaceous to Quaternary in age. These formations include Pabdeh and Gurpi marl formations, Asmari limestone formation, gypsum and marl layers Gachsaran formation, Mishan formation with limestone shellfish and Gray marl, Aghajari limy sandstone and red marls, Lahbari Member weathered siltstone from old to new, respectively. Alluvial sediments, that are the youngest sediments in the study area, are composed of gravel, sand silt and clay (Figure 1). Groundwater resources in the study area are located in alluvium. The aquifer average thickness is about $75 \mathrm{~m}$ in which sediments of Bakhtiari formation in the southwest and west and northwest of the study area made the bed rock and also sediments of Gachsaran formation with low infiltration in north and east and central parts. The general direction flow of groundwater is toward west throughout the area. Groundwater has been used for various purposes, such as drinking, agricultural, domestic, and industrial needs.

\section{Materials and Methods}

Water samples were obtained from 30 wells during Jul 2014. Two 250-ml bottles were collected at each site. The first sample, which was intended for anion analyses, was left unfiltered and unacidified. The filtered water of the second sample was acidified with $2 \mathrm{ml}$ of concentrated nitric acid (Merck, Ultrapure). The second sample was used later for heavy metals analysis. Physicochemical parameters including temperature, EC and $\mathrm{pH}$ were measured in situ using portable measuring instruments immediately after sampling. Dry, clean and sterilized polyethylene bottles were used for water sampling. The bottles were triple washed by the water to be sampled before sampling. The collected samples were labeled, sealed and transported to the laboratory and preserved in refrigerator at a temperature of about $4 \mathrm{C}$ until analysis. Water samples were analyzed for chemical constituents such as $\mathrm{HCO}_{3}^{2-}, \mathrm{SO}_{4}^{2-}, \mathrm{Cl}^{-}, \mathrm{Mg}^{2+}, \mathrm{Ca}^{2+}, \mathrm{Na}^{+}, \mathrm{K}^{+}$and TDS in the laboratory using titration flame photometry and evaporating a pre-filtered method respectively, within $48 \mathrm{~h}$ after sampling. Heavy metals were analyzed using optical emission spectrophotometer. Then, distribution pattern of each element was determined in the surfer software. After wards_correlation of heavy metals concentration and major anions and cations $\left(\mathrm{HCO}_{3}^{2-}, \mathrm{SO}_{4}^{2-}\right.$, $\mathrm{Cl}^{-}, \mathrm{Na}^{+}, \mathrm{Mg}^{2+}, \mathrm{Ca}^{2+}, \mathrm{K}^{+}$) was used to determine the probable sources of heavy elements contamination.

\section{Results and Discussion}

Hydro chemical results of groundwater revealed $\mathrm{Pb}$ content varies from 0 to $0.83 \mathrm{mg} / \mathrm{l}$ as $33 \%$ of the analyzed samples display content above the standard value (Figure 2). From its low correlation coefficient with major cations and anions it can be seen that $\mathrm{Pb}$ set on the soil and planets and penetrated to the groundwater in raining. The high concentration of cadmium in southwest and northwest parts of the area can be considered as the effects of Gachsaran formation and Cd tendency to substitute minerals containing Ca [4] (Figure 2). The high rate of $\mathrm{Cd}$ concentration in urban sewage water is due to the small industries, workshops and mills wastewater. As content 


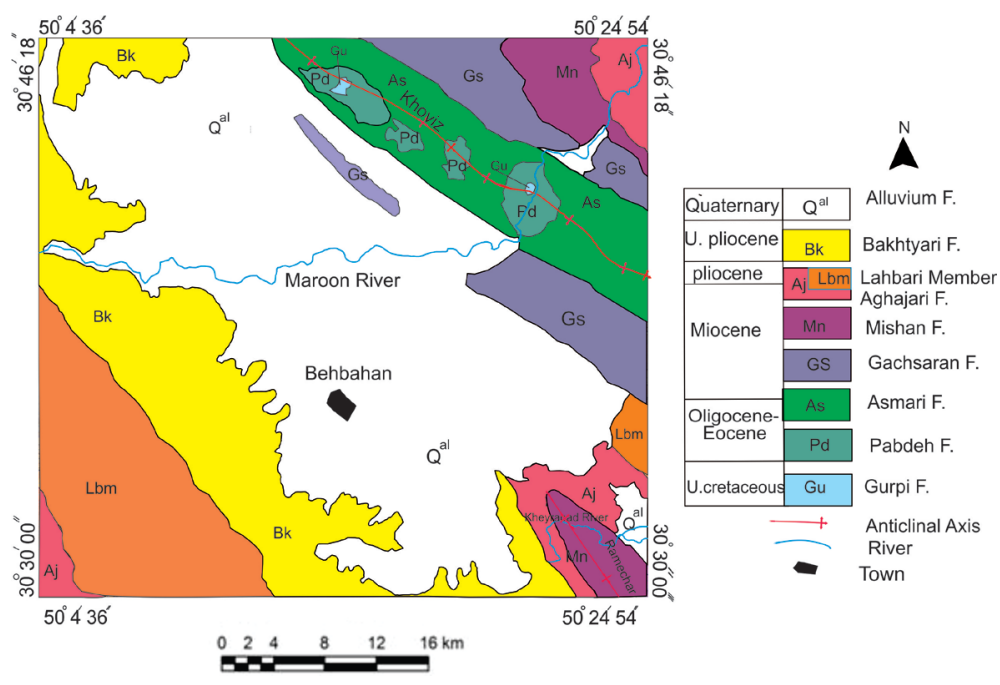

Figure 1. Geological setting of the study area.
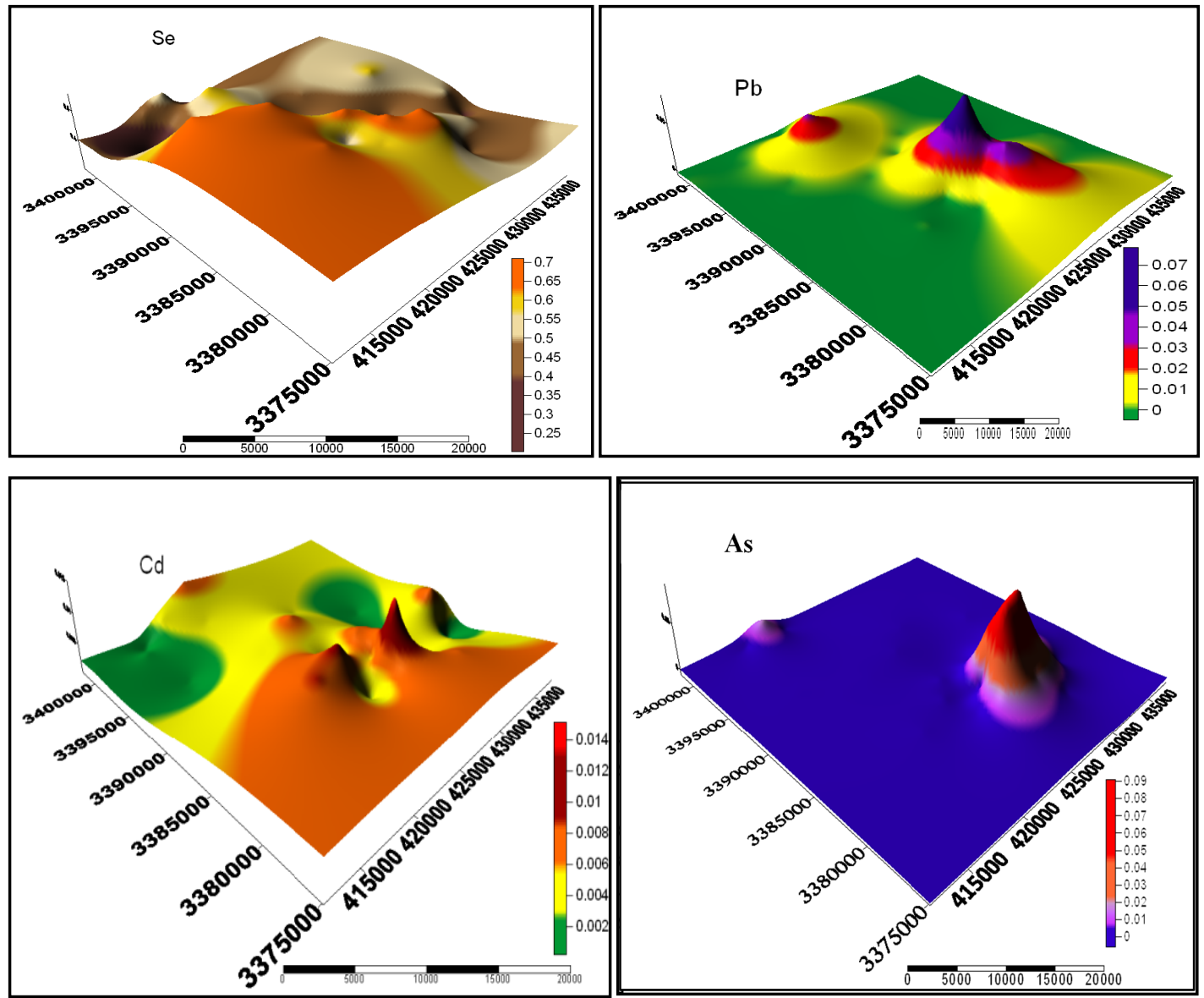

Figure 2. Geochemical map showing the concentration of heavy metals in the study area.

ranges from 0.009 to $0.094 \mathrm{mg} / \mathrm{l}$, whereby, $13 \%$ of samples exceed WHO standard (Table 1 ). According to high correlation between As and major cations and anions its high concentration in some parts of the area might possibly be related to the dissolution of evaporates minerals (Table 2). As concentration increase can be caused by pesticides used in garden and other agricultural land in urban and suburban areas (Figure 2). 
Table 1. Basic statistical parameters for the heavy metals.

\begin{tabular}{ccccccc}
\hline Parameters & Se & pb & cd & AS & 0.009 \\
Mean & 0.523 & 0.215 & 0.484 & 0.159 & 0.094 \\
Maximum & 0.691 & 0.838 & 0 & 0 & 0.024 \\
Minimum & 0.19 & 0 & 0 & 0.035 & 0.01 \\
Standard deviation & 0.124 & 0.02 & 0.01 & 0.03 & 56 \\
Maximum permissible limit (WHO) & 0.01 & 100 & 33 & & 56 \\
Samples exceeding maximum permissible limit (\%) & & &
\end{tabular}

Table 2. Pearson's correlation matrix of groundwater samples.

\begin{tabular}{|c|c|c|c|c|c|c|c|c|c|c|c|c|c|c|c|}
\hline & $\mathrm{PH}$ & TDS & EC & $\mathrm{K}^{+}$ & $\mathrm{Na}_{+}$ & $\mathrm{Mg}^{2+}$ & $\mathrm{Ca}^{2+}$ & $\mathrm{HCO}_{3}^{2-}$ & $\mathrm{CL}^{-}$ & $\mathrm{SO}_{4}^{2-}$ & $\mathrm{NO}_{3}^{-}$ & As & $\mathrm{Cd}$ & $\mathrm{Pb}$ & Se \\
\hline $\mathrm{PH}$ & 1 & & & & & & & & & & & & & & \\
\hline TDS & $\underline{0.05}$ & 1 & & & & & & & & & & & & & \\
\hline EC & $\underline{0.45}$ & $\underline{0.9}$ & 1 & & & & & & & & & & & & \\
\hline $\mathrm{K}^{+}$ & 0.32 & $\underline{0.64}$ & 0.65 & 1 & & & & & & & & & & & \\
\hline $\mathrm{Na}^{+}$ & 0.35 & $\underline{0.84}$ & $\underline{0.88}$ & $\underline{0.7}$ & 1 & & & & & & & & & & \\
\hline $\mathrm{Mg}^{2+}$ & 0.22 & $\underline{0.53}$ & 0.49 & 0.38 & 0.3 & 1 & & & & & & & & & \\
\hline $\mathrm{Ca}^{2+}$ & 0.31 & 0.48 & 0.48 & 0.15 & 0.17 & 0.36 & 1 & & & & & & & & \\
\hline $\mathrm{HCO}_{3}^{2-}$ & 0.34 & 0.36 & 0.38 & 0.04 & 0.43 & 0.12 & 0.1 & 1 & & & & & & & \\
\hline $\mathrm{CL}^{-}$ & 0.31 & 0.16 & 0.18 & 0.01 & 0.11 & 0 & 0.21 & 0.12 & 1 & & & & & & \\
\hline $\mathrm{SO}_{4}^{2-}$ & 0.37 & $\underline{0.82}$ & $\underline{0.76}$ & 0.44 & $\underline{0.5}$ & $\underline{0.66}$ & $\underline{0.73}$ & 0.18 & 0.06 & 1 & & & & & \\
\hline $\mathrm{NO}_{3}^{-}$ & 0.04 & 0.02 & 0.25 & 0 & 0 & 0.01 & 0.22 & 0 & 0.11 & 0.04 & 1 & & & & \\
\hline As & 0.23 & $\underline{0.69}$ & 0.7 & 0.48 & $\underline{0.64}$ & 0.24 & 0.22 & 0.19 & 0.2 & 0.42 & 0.06 & 1 & & & \\
\hline $\mathrm{Cd}$ & 0 & 0.05 & 0.04 & 0 & 0 & 0 & 0.33 & 0 & 0.18 & 0.11 & 0.22 & 0.1 & 1 & & \\
\hline Se & 0.21 & 0.05 & 0.2 & 0.2 & 0.01 & 0.21 & 0.39 & 0.09 & 0.08 & 0.21 & 0.2 & 0.08 & 0.04 & 0 & 1 \\
\hline
\end{tabular}

In general, Se is vital for regulating biological processes in human bodies; however, beyond the permissible limit it can cause health hazards. Se content ranges from 0.52 to $0.69 \mathrm{mg} / \mathrm{l}$ where by $100 \%$ of samples exceed WHO standard (Table 1). Relatively good correlation coefficient is also observed between Se and $\mathrm{Mg}^{2+}+\mathrm{Ca}^{2+}$ and $\mathrm{SO}_{4}^{2-}$, which indicates the dissolution of gypsum and dolomite as the main source of selenium (Table 2). Geochemical evaluation (Figure 2) shows the nearly uniforms concentration of Se in the study area.

Also hydro chemical results of the groundwater revealed that concentration of $\mathrm{Zn}$ and Co was below the water standards. Concentration of Cobalt and zinc is dependent on the bed rock (Mico, 2006). The low concentration of $\mathrm{Co}$ and $\mathrm{Zn}$ is compatible with geochemical characteristics of alluvium plain.

The metal index (MI) can be used for trend evaluation of the pollution status. According to [5], the MI is calculated using the Equation (1):

$$
M I=\sum_{i=1}^{n} \frac{C_{i}}{(M A C)_{i}}
$$

where, $C_{i}$ : the concentration of each element, MAC: maximum allowable concentration (from the WHO standard).

The higher the concentration of a metal compared to its respective $M A C$ value, the worse the quality of the water. $M I$ value $>1$ is a threshold of warning [6]. The metal index is used to estimate the metal pollution of ground water in the study area for drinking. Metal index denotes the trend evaluation of the present status by computing $\mathrm{Pb}, \mathrm{Cd}$, As, Se concentrations (Table 3). According to metal index values, all selected stations in 
Table 3. Metal index for water drinking in Behbahan plain.

\begin{tabular}{cccc}
\hline Number of well & Metal Index & Number of well & Metal Index \\
\hline 1 & 71.38 & 16 & 71.66 \\
2 & 59.7 & 17 & 37.8 \\
3 & 39.06 & 18 & 53.2 \\
4 & 50.03 & 19 & 53.73 \\
5 & 65.54 & 20 & 62.61 \\
6 & 40.36 & 21 & 59.2 \\
7 & 58.46 & 22 & 38.37 \\
8 & 39.16 & 23 & 50.18 \\
9 & 44.1 & 24 & 71.85 \\
10 & 42.4 & 25 & 71.99 \\
11 & 19.66 & 26 & 56.41 \\
12 & 68.34 & 27 & 47.72 \\
13 & 51.5 & 28 & 56.06 \\
14 & 71.07 & 29 & 82.66 \\
15 & 70.7 & 30 & 78.99 \\
\hline
\end{tabular}

Behbahan plain threatened with metal pollution for drinking usage (MI > 1).

\section{Conclusion}

The hydrochemical analysis of the present study reveals that the groundwater in the study area is contaminated with trace metals, such as $\mathrm{Cd}$, Se, As and $\mathrm{Pb}$. The mean concentration of heavy metals (mg/l) displays the following decreasing trend: $\mathrm{Se}>\mathrm{Pb}>\mathrm{As}>\mathrm{Cd}$. The spatial distribution maps of Cadmium, Selenium, Arsenic and Lead showed that the maximum concentration of Se, As, Cd, Pb occurs in the southern part of the study area and their concentration decreases towards the north-west. Due to correlation coefficient of elements of $\mathrm{As}$, Se, $\mathrm{Pb}$, $\mathrm{Cd}$, and major cations and anions, dissolution evaporates minerals can be considered as probable sources of As, $\mathrm{Se}$, while probable sources of $\mathrm{Cd}, \mathrm{Pb}$ consist of anthropogenic activities. Metal index indicates that the groundwater quality is severally deteriorating. The overall quality states that Behbahan Plain is an area which demands urgent attention and the results of this paper are important for the development of proper management and remediation strategies to decrease source pollution.

\section{Acknowledgements}

This work was supported by the Behbahan branch of Islamic Azad University. We would like to thank this department.

\section{References}

[1] Jameel, A. and Sirajudeen, J. (2006) Risk Assessment of Physicochemical Contaminants in Groundwater of Pettavaithalai Area, Tiruchirappalli, Tamilnadu, India. Environmental Monitoring and Assessment, 123, 299-312.

[2] Marghade, D., Malpe, D.B. and Zade, A.B. (2011) Geochemical Characterization of Groundwater from Northeastern Part of Nagpur urban, Central India. Environmental Earth Sciences, 62, 1419-1430. http://dx.doi.org/10.1007/s12665-010-0627-y

[3] Singh, C.K., Rina, K., Singh, R.P. and Mukherjee, S. (2013) Geochemical Characterization and Heavy Metal Contamination of Groundwater in Satluj River Basin. Environmental Earth Sciences, 71, 14. 
[4] Langmuir, D. (1997) Aqueous Environmental Geochemistry. Prentice-Hall, 600 p.

[5] Tamasi, G. and Cini, R. (2004) Heavy Metals in Drinking Waters from Mount Amiata. Possible Risks from Arsenic for Public Health in the Province of Siena. Science of the Total Environment, 327, 41-51. http://dx.doi.org/10.1016/j.scitotenv.2003.10.011

[6] Bakan, G., Boke Ozkoc, H., Tulek, S. and Cuce, H. (2010) Integrated Environmental Quality Assessment of Kiz1lırmak River and Its Coastal Environment. Turkish Journal of Fisheries and Aquatic Sciences, 10, 453-462. 